\title{
A NEW SPECIES OF AMEROSEIUS (ACARI: MESOSTIGMATA, AMEROSEIIDAE) FROM BRASIL 1
}

CARLOS H. W. FLECHTMANN ${ }^{2}$ CARLOS A. H. FLECHTMANN 3

\begin{abstract}
A new species in the genus Ameroseius, viz. dendrovagans, is described and figured. It was collected in bark beetle (Scolytidae, Coleoptera) galleries in Pinus sp. in Minas Gerais, Brasil.
\end{abstract}

\section{INTRODUCTION}

Representatives of the family Ameroseiidae Evans, 1963 are poorly known in South America. The present study seems to be the first report on the presence of Ameroseius in Brasil. Also, emphasis on the biological control of injurious insects demands the identification of all their biological associates by the economic workers.

\section{Ameroseius dendrovagans, sp. n.}

Female: Dorsal shield entire, covering idiosoma entirely and overhanging the gnathosoma. This shield is brownish, ornamented with strong ridges forming a reticulate pattern and dimples; it bears 28 pairs of setae; these are mostly sickle-shaped, with rows of short pectinations. Some setae long, but the longest not reaching half of body width. Tectum broadly triangular, pointed anteriorly. Corniculi robust, trifid. Palpal apotele bifid. Fixed digit of chelicera with three proximal teeth. Tritosternum with a long base; laciniae short. Sternal shield bears 2 pairs of sternal setae; provided with line ornamentations. Sternal setae III situated on separate shields behind the posterolateral angulations of sternal shield. Metasternal setae on the cuticle. Genital shield with 1 pair of setae; with line ornamentations except for anterior flaps, whose anterior margin is not always clearly visible. Two pairs of pore-like structures are situated on the cuticle near the postero-lateral margin of the genital shield. Peritremes long, extending anteriorly to coxae I. Ventro-anal shield ellyptic, as figured. All legs with ambulacra.

Dimensions: length of dorsal shield $418 \mu \dot{\mathrm{m}}$; greatest width $273 \mu \mathrm{m}$. Measurements of additional 5 females: $391 \times 255 ; 432 \times 289 ; 425 \times 269 ; 381 \times 241$; $421 \times 269 \mu \mathrm{m}$.

Male: Dorsal shield with the same general features as in females. Sternogenital shield with 5 pairs of setae; genital opening in an anterior invagination, presternal; well separated from the ventro-anal shield. Fixed digit of chelicera with three proximal teeth; movable digit with a spermatodactyl.

Dimensions (of 2 specimens): length of dorsal shield $302 \mu \mathrm{m}$; greatest width $187 \mu \mathrm{m}$.

Material examined: female holotype from the galleries of bark beetles (Coleoptera, Scolytidae) in Pinus sp., Sacramento, Minas Gerais, Brasil, May 1982 (Evoneo Berti F.). Allotype male; 5 paratype females and 2 paratype males same data. Deposited at Dept. Zoology, ESALQ - Univ. São Paulo, Piracicaba, SP, No. 1370.

1. Supported, partially, by Conselho Nacional de Desenvolvimento Científico e Tecnológico, $\mathrm{CNPq}$, Brasil.

2. Depto. Zoologia, ESALQ - Univ. São Paulo, 13400 Piracicaba, SP, Brasil.

3. Student, fellow of Instituto de Pesquisas e Estudos Florestais, SP, Brasil. 

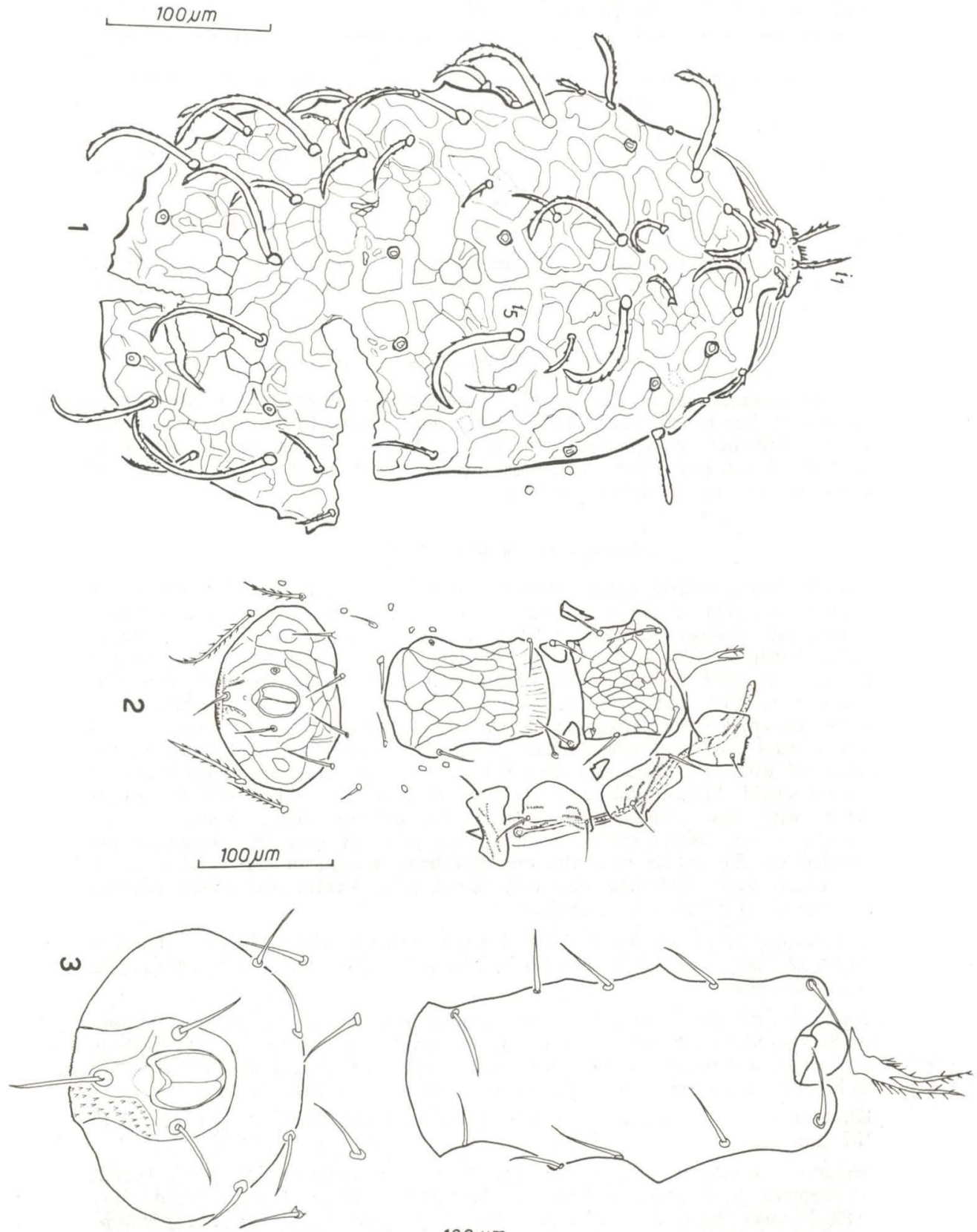
of female. 3. Ventral aspect of male. 


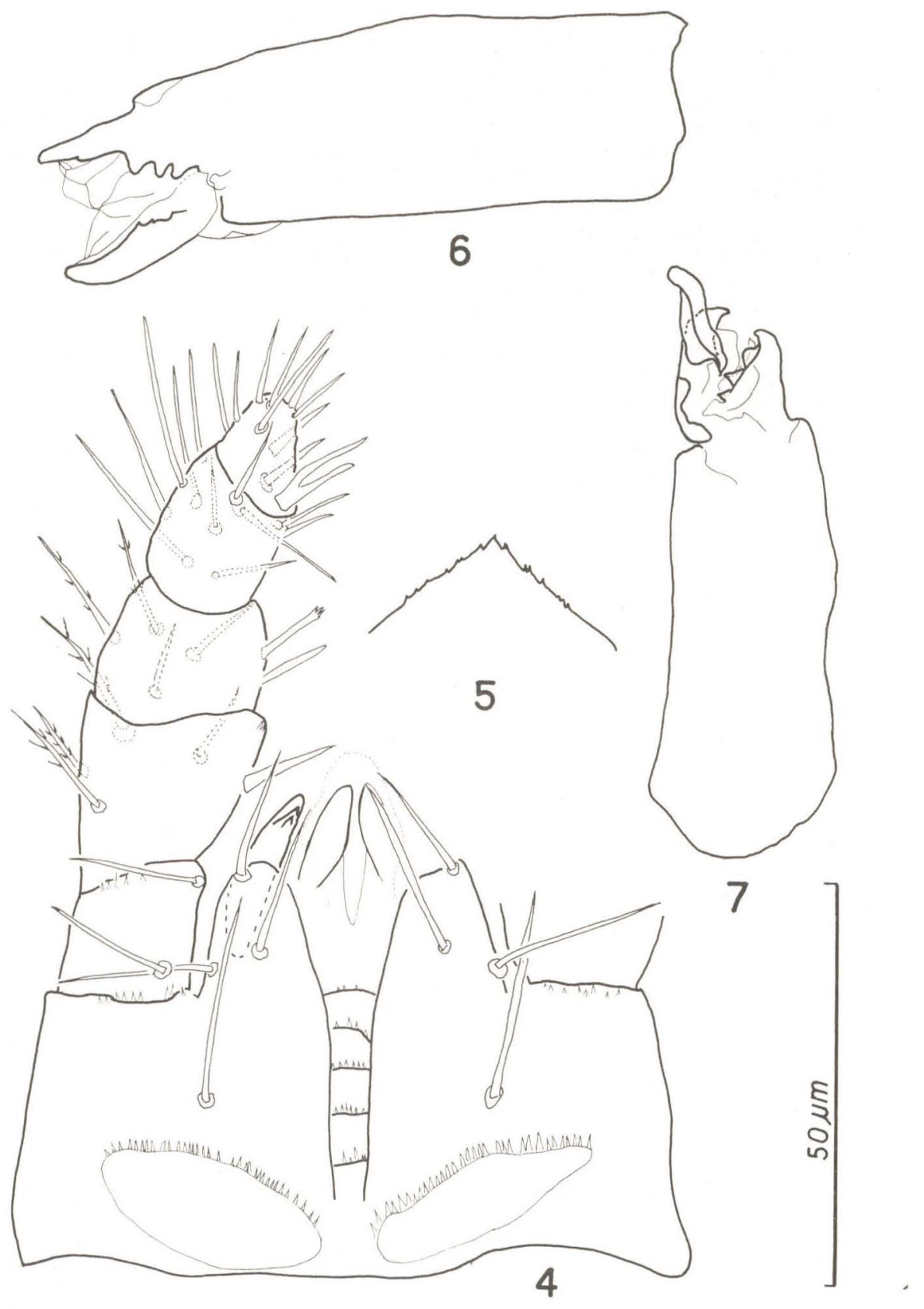

Ameroseius dendrovagans, sp. n. ․ 4. Hypostome, ventral. 5. Tectum. 6-7. Chelicera. 
Derivation of the name: from dendron $($ Greek $=$ tree $)+$ vagans $($ Latin $=$ wandering on).

Diagnosis: Ameroseius dendrovagans is close to A. corniculus Karg, 1957, A. imparsetosus Westerboer, 1963 and $A$. cavernosus Westerboer, 1963. It is readily separated from $A$. corniculus by its spiniform $\mathrm{i}_{1}$ setae (bushy in corniculus); from imparsetosus by the shorter $\mathrm{i}_{5}$ setae (longer than half of body width in imparsetosus, shorter in dendrovagans); and from cavernosus by the structure of the dorsal setae (slender, almost needlelike in cavernosus; robust in dendrovagans).

Remarks: comments on its life cycle and biology are being published by Fechtmann, 1985, Revta bras. Zool. 2(6): 397-399.

\section{REFERENCES}

Karg, W., 1971. 59. Teil. Acari (Acarina), Milben. Unterordnung Anactinochaeta (Parasitiformes). Die freilebenden Gamasina (Gamasides), Raubmilben. In: Dahl, F. \& F. Peus, Die Tierwelt Deutschlands. G. Fisher, Jena, 1-475.

Westerboer, I., 1963. Die Familie Podocynidae Berlese, 1916. In: Stammer, H. J., Beitraege zur Systematik und Oekologie mitteleuropaeischer Acarina. Bd. II: Mesostigmata. 1. Leipzig, 1-804. 